\title{
Response surface optimization of polysaccharide extraction from Galla Chinensis and determination of its antioxidant activity in vitro
}

\author{
Jiangxia $\mathrm{HU}^{1}$, Jiayu $\mathrm{GAO}^{1 \star}$ (ID), Zijun $\mathrm{ZHAO}^{1}$, Xiao $\mathrm{YANG}^{2}$
}

\begin{abstract}
Galla Chinensis was a traditional Chinese medicine used as an ingredient in many prescriptions for the treatment of oxidant damage-associated symptoms in China. The current research on the isolation of polysaccharides from Galla Chinensis and their antioxidant activities still remain as an ongoing challenge. The purpose of this study is to develop an isolation technique for polysaccharides from Galla Chinensis and determine their antioxidant properties in vitro. An ultrasonic-assisted method of polysaccharides extraction from Galla Chinensis were firstly developed and the key parameters were optimized response surface analysis as crushing degree $100 \mathrm{mesh}$, ultrasonic time $20 \mathrm{~min}$, and materials/liquid ratio 1: 40. The polysaccharides presented dose-dependent antioxidant and free radical scavenging effects in DPPH, ABTS, total antioxidant and Iron ion reduction assays. Moreover, it also demonstrated an effective protective effect for human under $\mathrm{H}_{2} \mathrm{O}_{2}$-induced oxidative damage on human embryonic kidneyfibroblast 293 and hepatoma 7721 cells by cell proliferation assay. The study firstly determined the antioxidant activities of polysaccharides from Galla Chinensis, thus providing a new natural resource for future investigation and development of the polysaccharides-based antioxidant drugs, health products or addictives.
\end{abstract}

Keywords: Galla Chinensis; polysaccharide; antioxidant; response surface analysis.

Practical Application: As the candidate of bioactive component for ameliorating oxidant damage-associated diseases.

\section{Introduction}

Galla Chinensis, used as a Traditional Chinese Medicine (TCM), is in a form of the gall produced through parasitic interaction between plants (family Anacardiaceae, mainly Rhus chinensis Mill, Rhus potaninii Maxim, and Rhus punjabensis var. sinica (Diels) Rehd. EtWils) and insects (Chinese sumac aphid Baker, mainly Melaphis chinensis Bell) (State Pharmacopoeia Committee of the People's Republic of China, 2015). This horned and reddish-brown gall, covered with the velvety down, is traditionally used to treat various body inflammatory diseases, such as toothache, dental caries, diarrhea, dysentery, painful hemorrhoids, and cancers in the many northeast and southeast Asian countries, especially in China (Sariozlu \& Livanc, 2011; Wang et al., 2019). Moreover, Galla Chinensis was also claimed to be used as an ingredient in many prescriptions for the treatment of oxidant damage-associated symptoms in the TCM encyclopedia (Gao et al., 2018).

Based on its empirical uses for oxidative damage diseases, such as cancers, cardiovascular diseases, degenerative diseases and metabolic diseases, Galla Chinensis recently create a great interest of scientific community toward its antioxidant and free radical scavenging potentials. Gallic acid, ellagic acid, $\beta$-sitosterol, amentoflavone and purpurogallin were most frequently investigated and considered as the antioxidant compounds of Galla Chinensis. Their protective role in preventing various oxidative damage diseases have widely reported toward the various application potentials in recent years (Chen et al., 2018; Farbood et al., 2019; Kahkeshani et al., 2019; Ponnulakshmi et al.,
2019; Xie et al., 2019). However, as the complex plant-insect symbiont, bioactive processes during galls formation suppose to generate abundance of bioactive metabolites in Galla Chinensis. The understanding of its phytochemical knowledge thus clearly needs further complement.

Polysaccharides is the main antioxidant ingredient of many herbal medicines, which has the functions of increasing antioxidant enzyme activity, eliminating free radicals, inhibiting lipid peroxidation and protecting the cells, tissues and organs under oxidative stress (Liu et al., 2018). Previously, a broad of polysaccharides isolated from traditional plants have been reported to exhibit strong antioxidant and free radical scavenging activities (Chen \& Huang, 2019; Gao et al., 2016, 2019). However, the bioactivities of polysaccharides from Galla Chinensis were barely reported. A systematic investigation into the isolation technique and antioxidant activities of the plant-insect symbiont polysaccharides thus remained an ongoing challenge.

To underpin a fundamental understanding of bioactive materials and antioxidant activities of Galla Chinensis and support its ongoing clinical uses in China, this study firstly developed and optimized an ultrasonic-assisted extraction method by response surface analysis to isolate polysaccharides from Galla Chinensis. Secondly, the antioxidant and free radical scavenging activities of extracted polysaccharides were determined by chemical and cellular analysis. 


\section{Materials and methods}

\subsection{Sample preparation and cell lines}

Galla Chinensis was purchased from Hao Yi Sheng Chinese herbal medicine store, Luoyang. The identity of original medicine was kindly confirmed as Galla Chinensis by Professor Pu Liu at Henan University of Science and Technology. A voucher specimen has been deposited in natural products research laboratory, School of Chemical Engineering and Pharmaceutics.

The dry herb was minced to proposed crushing degree $(60,80,100$ or 120 mesh). The samples were then extract with distilled water at proposed ratio $(1: 5,1: 10,1: 20,1: 30$ or $1: 40)$ in the ultrasonic cleaning machine for proposed minutes $(10 \mathrm{~min}$, $20 \mathrm{~min}, 30 \mathrm{~min}, 40 \mathrm{~min}$ or $50 \mathrm{~min}$ ) at $60{ }^{\circ} \mathrm{C}$. The samples were then centrifuged and collected supernatants. The supernatants were mixed with absolute ethanol to achieve the final ethanol concentration at $80 \%$. The mixture was standstill for 12 hours and centrifuged to precipitate the polysaccharides.

The human embryonic kidneyfibroblast cells 293 and hepatoma cells 7721 were purchased from Beinglay Biotech (Wuhan, Hubei, China). Cells were grown in DMEM medium in a $5 \%$ carbon dioxide humidified incubator at $37^{\circ} \mathrm{C}$.

\subsection{Response surface analysis}

According to the results of single factor test, factor A crushing degree (60, 80 and 100 mesh), factor B ultrasonic extraction time (20, 30 and $40 \mathrm{~min})$ and factor $\mathrm{C}$ materials/liquid ratio (1:20, 1: 30 and 1: $40 \mathrm{~g} / \mathrm{mL}$ ) were selected for response surface analysis. In the response surface analysis of Design-Expert 8.0.6, Box-Behnken was selected to perform the experimental design with three factors and three levels.

\subsection{DPPH free radical scavenging assay}

Prepared polysaccharides and Vitamin C at concentration of $0.01,0.03,0.06,0.12,0.18,0.24 \mathrm{mg} / \mathrm{mL}$. The $3 \mathrm{~mL} \mathrm{DPPH}$ working solution was mixed with $1 \mathrm{~mL}$ sample. The mixtures were then incubated at room temperature for $30 \mathrm{~min}$ and measure the absorbance at $517 \mathrm{~nm}$. DPPH free radical scavenging rate $=\left(A_{0}-\left(A_{S}-A_{C}\right)\right) / A_{0}^{*} 100 \% . A_{0}$ : absorbance of DPPH working solution+ absorbance of distilled water; $\mathrm{A}_{\mathrm{S}}$ : absorbance of DPPH working solution+ absorbance of samples; $A_{c}$ : absorbance of distilled water+ absorbance of samples.

\subsection{ABTS free radical scavenging assay}

Prepared polysaccharides and Vitamin $\mathrm{C}$ at concentration of $0.01,0.02,0.03,0.06,0.12,0.24 \mathrm{mg} / \mathrm{mL}$. The $2.4 \mathrm{~mL}$ ABTS working solution was mixed with $0.6 \mathrm{~mL}$ sample. The mixtures were then shake for $6 \mathrm{~min}$ in dark and measure the absorbance at $734 \mathrm{~nm}$. ABTS free radical scavenging rate $=\left(A_{0}-\left(A_{S}-A_{C}\right)\right) / A_{0}{ }^{*} 100 \% . A_{0}$ : absorbance of ABTS working solution + absorbance of distilled water; $A_{s}$ : absorbance of ABTS working solution+ absorbance of samples; $A_{c}$ : absorbance of distilled water+ absorbance of samples.

\subsection{Total antioxidant activity test}

Prepared polysaccharides and Vitamin $\mathrm{C}$ at concentration of $0.06,0.12,0.18,0.24,0.30,0.36 \mathrm{mg} / \mathrm{mL}$. Prepared the stock solution of phosphorus molybdenum reagent $(0.6 \mathrm{~mol} / \mathrm{L}$ sulfuric acid, $28 \mathrm{mmol} / \mathrm{L}$ sodium phosphate and $4 \mathrm{mmol} / \mathrm{L}$ ammonium molybdate). The $1.0 \mathrm{~mL}$ of each samples mixed with $3.0 \mathrm{~mL}$ phosphorus molybdenum reagent solution and placed in $95^{\circ} \mathrm{C}$ water bath for $90 \mathrm{~min}$. The samples were cooled down and measured the absorbance at $625 \mathrm{~nm}$.

\subsection{Iron ion reduction assay (FRAP)}

Prepared polysaccharides and Vitamin $\mathrm{C}$ at concentration of $0.02,0.04,0.06,0.08,0.10$ and $0.12 \mathrm{mg} / \mathrm{mL}$. Prepared $\mathrm{FeSO}_{4}$ solution at concentration of $400,200,100,50,25 \mu \mathrm{mol} / \mathrm{L}$. Dissolved $31.233 \mathrm{mg}$ tripyridyl triazine in $40 \mathrm{~mL} 10 \mathrm{mmol} / \mathrm{L}$ HCL to produce $10 \mathrm{mmol} / \mathrm{L}$ TPTZ solution. The $3.6 \mathrm{~mL} \mathrm{FRAP}$ working solution was mixed with $0.4 \mathrm{~mL}$ samples. The mixtures were shaken and measured the absorbance at $593 \mathrm{~nm}$. Used series concentrations of $\mathrm{FeSO}_{4}$ solution to produce the standard curve and then determined the $\mathrm{FeSO}_{4}$ concentrations in the samples as FRAP values representing the antioxidant ability.

\subsection{Cell antioxidant assay}

$200 \mu \mathrm{L}$ cell suspension was seeded at a concentration of $1.5 \times 10^{4}$ cells $/ \mathrm{mL}$ in a 96 -well plate. After overnight incubation, $\mathrm{H}_{2} \mathrm{O}_{2}(1000,10$ and $0.1 \mu \mathrm{g} / \mathrm{mL})$ and serial dilutions of polysaccharides $(1000,500,100$ and $10 \mu \mathrm{g} / \mathrm{mL})$ were added in $10 \mu \mathrm{L}$ aliquots. After 6 and 24 hours incubation, $20 \mu \mathrm{L}$ MTT solution $(5 \mathrm{mg} / \mathrm{mL})$ was added and incubated at $37^{\circ} \mathrm{C}$ for $4 \mathrm{~h}$ to develop color. The optical density (OD) was measured at $590 \mathrm{~nm}$ using a Multiskan Spectrum Reader. The cell survive rate was determined using cell survive rate $=$ sample O.D/control O.D $\times 100 \%$.

\subsection{Statistical analysis}

The data were shown as mean \pm standard deviation (SD). Statistical comparison among treatments was carried out using one-way analysis of variance (ANOVA). The statistical significances between control and sample groups were calculated by the Student's t-test. Data were taken as significant where $\mathrm{p}<0.05$.

\section{Results and discussion}

In the single factor experiment, crushing degree, materials/liquid ratio, ultrasonic times and temperature were selected to be the parameter optimized during the polysaccharides isolation of Galla Chinensis. As shown in Figure 1A and C, the extraction rate of polysaccharides increased at first and then decreased at the different crushing degree and ultrasonic time. The extraction rate reached the top value at 80 crushing meshes and 30 minutes, respectively. The 60, 80 and 100 meshes, and 20, 30 and 40 minutes were chosen to be used in following response surface analysis. Moreover, the extraction rate raised with the increase in materials/liquid ratio as shown in Figure 1B, The ratios of 1:20, 1:30 and 1:40 were used in further analysis.

The water extraction following alcohol sedimentation is the most common method used for natural polysaccharides 
isolation (Zhao et al., 2019). However, the parameters, such as materials/liquid ratio, ultrasonic time, extraction temperature, alcohol concentration, extraction repeating times, and crushing degree of raw materials, all could play the roles affecting the extraction efficiency (Shi, 2016). In the preliminary isolation tests of current study, crushing degree of raw materials, materials/liquid ratio and ultrasonic time were determined as the key factor and then optimized using response surface analysis. It was found that the smaller size of herbal raw materials could increase the contact area with extracting liquid, which enhance the extraction. However, too small size materials may led to the accumulation and caking of samples, thus decreasing the extraction rate. Appropriate enhancement of the ultrasound time also increased the extraction of polysaccharides. But the extensive period of ultrasonic concussion may lead to the destruction of polysaccharide macromolecule, thus decreasing the extraction rate (Shang et al., 2019). The higher materials/liquid ratio enhances the mutual contact and extraction between materials and solvent. Considering the solvent and energy consumption, materials/liquid ratio should also be controlled within a rational range.

As shown in Table 1, the parameters selected above were used to perform the response surface analysis using Box-Behnken of Design-Expert 8.0.6. The results obtained were then merged and optimized to produce the Formula 1 as follows:
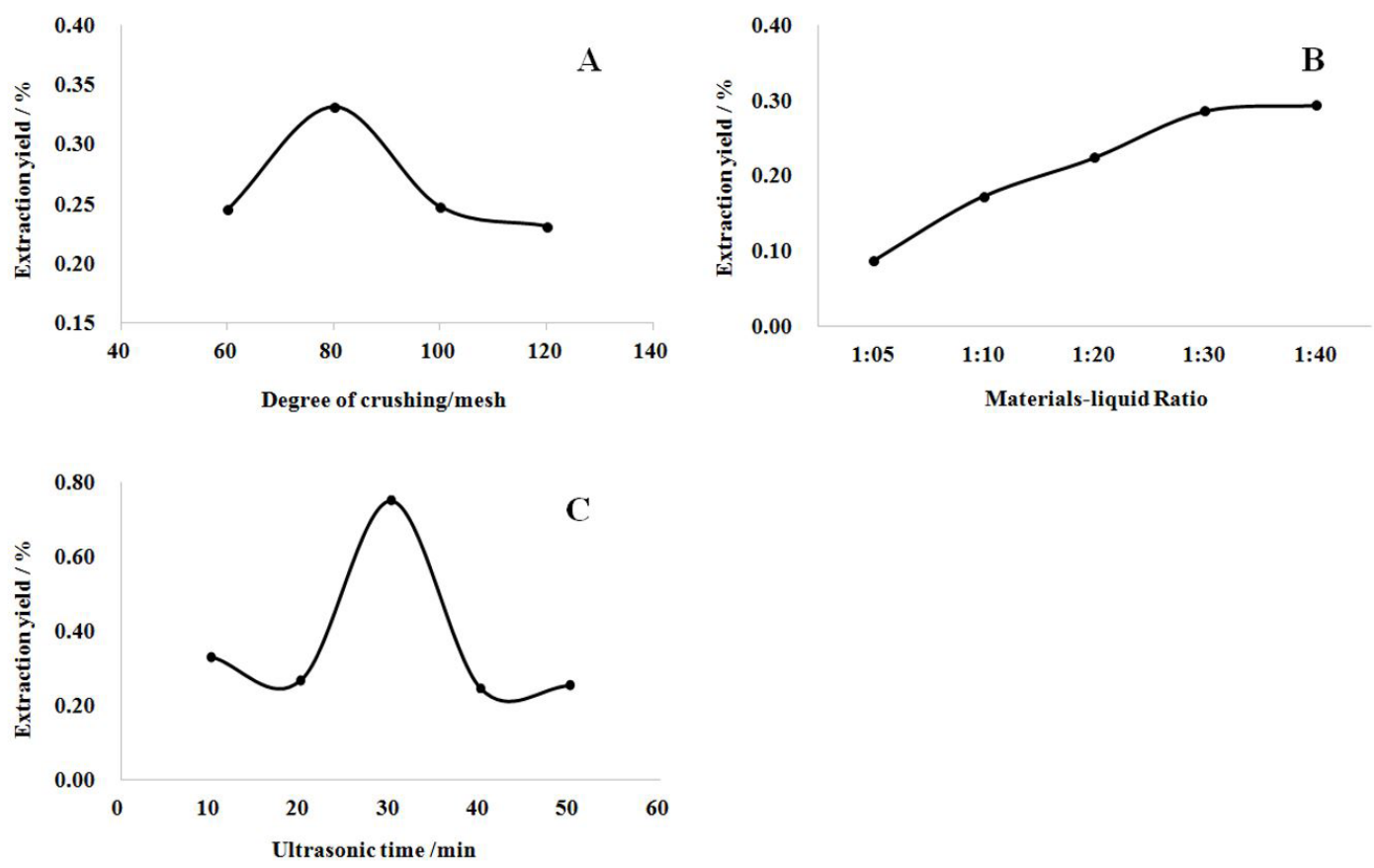

Figure 1. Single factor experiment of polysaccharides isolation from Galla Chinensis. (A) Degree of crushing/mesh; (B) Materials-liquid Ratio; (C) Ultrasonic time/min.

Table 1. Experimental scheme and results.

\begin{tabular}{ccccc}
\hline No & A crushing degree/mesh & B ultrasonic extraction time/min & C materials/liquid ratio/g $\mathrm{mL}^{-1}$ & Extraction Rate/\% \\
\hline 1 & 100 & 30 & 40 & 0.52 \\
2 & 80 & 30 & 30 & 0.32 \\
3 & 60 & 30 & 20 & 0.24 \\
4 & 80 & 20 & 40 & 0.43 \\
5 & 80 & 30 & 30 & 0.33 \\
6 & 60 & 20 & 30 & 0.19 \\
7 & 60 & 30 & 40 & 0.30 \\
8 & 100 & 40 & 30 & 0.40 \\
9 & 80 & 40 & 20 & 0.50 \\
10 & 100 & 30 & 20 & 0.51 \\
11 & 80 & 30 & 30 & 0.35 \\
12 & 80 & 40 & 40 & 0.35 \\
13 & 80 & 30 & 30 & 0.30 \\
14 & 60 & 40 & 30 & 0.26 \\
15 & 80 & 30 & 30 & 0.29 \\
16 & 100 & 20 & 30 & 0.40 \\
17 & 80 & 20 & 20 & 0.21 \\
\hline
\end{tabular}


Extraction Rate $(Y)=0.320825702+0.104134237 * A+$ $0.032408266 * B+0.018277963 * C-0.016505191 * A * B-$

$0.091808792 * B * C-0.012389854 * B^{2}+0.068056154 * C^{2}$

As shown in Table 2, the model $\mathrm{P}$ value was less than 0.001 and the missing item $P$ values was less than 0.2549 , which indicated that the model was fully fitted and could well described the relationship between each factor and the response value. The determination coefficient $\mathrm{R}^{2}$ of the regression equation above was 0.9549 . The corrected correlation coefficient $\mathrm{R}_{\text {adj }} 2$ was 0.9199 , which showed that the variability of the test data could be explained by this regression model. Therefore, the model could be used to predict the extraction rate of Galla Chinensis polysaccharides. Moreover, the $\mathrm{P}$ value of primary item A was less than 0.001 with the extremely significant difference. The $P$ value of quadratic term item $\mathrm{BC}$ and $\mathrm{C}^{2}$ was less than 0.01 with the highly significant difference. The $\mathrm{P}$ value of primary item $\mathrm{B}$ was significantly difference. The $\mathrm{P}$ value of primary item $\mathrm{C}$ was not significantly difference. The results showed that the extraction rate of Galla Chinensis polysaccharides was not determined by a single factor, but by a variety of interactive factors. According to their $\mathrm{P}$ values, it could be concluded that the influence levels was crushing degree $(\mathrm{A})>$ ultrasonic time $(\mathrm{B})>$ ratio of materials/liquid $(\mathrm{C})$.

The optimum extraction conditions for polysaccharides of Galla Chinensis were determined using the regression model above as follows: crushing degree $100 \mathrm{mesh}$, ultrasonic time $20 \mathrm{~min}$, and materials/liquid ratio 1: 40. Natural polysaccharides isolation optimized by response surface analysis has been exhaustively reported and reviewed elsewhere (Bargougui et al., 2019; Xue et al., 2019). The constructed regression model could accurately predict the extraction rate of polysaccharides in this work. The actual extraction value was validated as $0.54 \%$, which was closed to the predicted value $(0.57 \%)$ in a great extent with fractional error less than $5 \%$.

In the DPPH assay, polysaccharides of Galla Chinensis presented the dose-dependent free radical scavenging effects as shown in Figure 2A. The maximum clearance rate was as

Table 2. Variance analysis.

\begin{tabular}{|c|c|c|c|c|}
\hline Source of variance & mean square & F value & $P$ value & significant \\
\hline model & 0.022 & 27.25 & $<0.0001$ & $* * *$ \\
\hline A-crushing degree & 0.087 & 108.52 & $<0.0001$ & $* * *$ \\
\hline B- ultrasonic extraction time & $8.40 \mathrm{E}-03$ & 10.51 & 0.0101 & * \\
\hline C- materials/liquid ratio & $2.67 \mathrm{E}-03$ & 3.34 & 0.1007 & \\
\hline $\mathrm{AC}$ & $1.09 \mathrm{E}-03$ & 1.36 & 0.273 & \\
\hline $\mathrm{BC}$ & 0.034 & 42.18 & 0.0001 & ** \\
\hline$A^{\wedge} 2$ & $6.48 \mathrm{E}-04$ & 0.81 & 0.3913 & \\
\hline$C \wedge 2$ & 0.02 & 24.46 & 0.0008 & ** \\
\hline residual & 7.99E-04 & & & \\
\hline missing item & $1.03 \mathrm{E}-03$ & 2.04 & 0.2549 & - \\
\hline pure error & 5.07E-04 & & & \\
\hline
\end{tabular}

${ }^{* * *} \mathrm{p}<0.001$ extremely significant; ${ }^{* *} \mathrm{p}<0.001$ highly significant; ${ }^{*} \mathrm{p}<0.05$ significant.

A
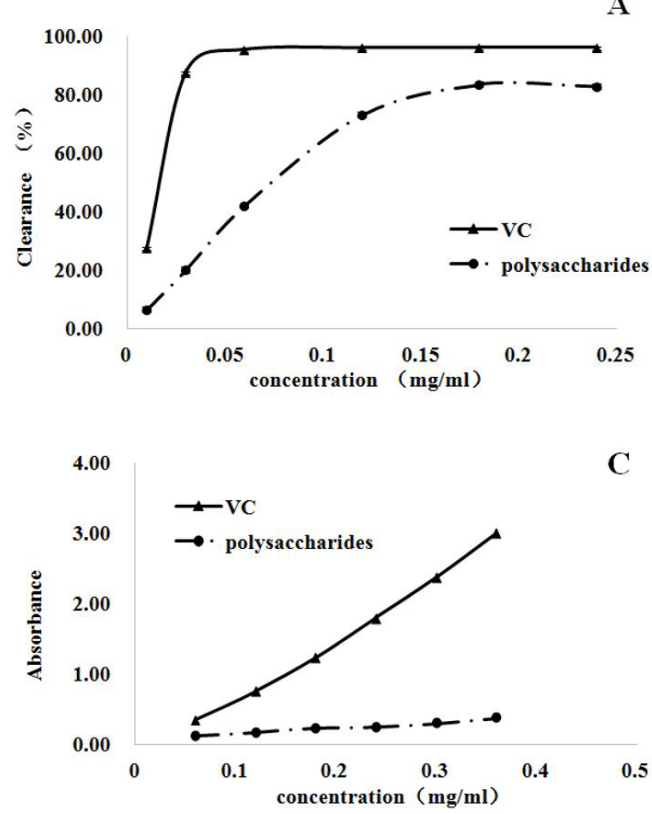

B

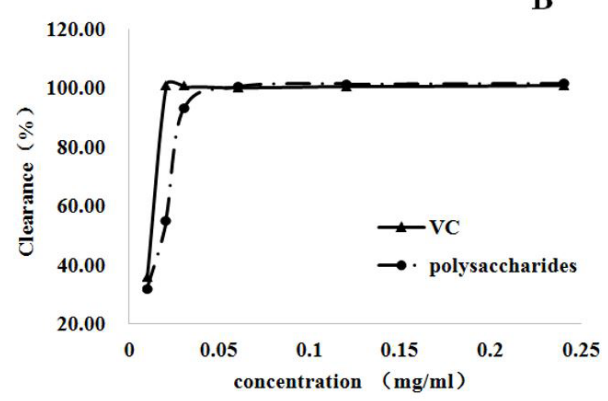

D

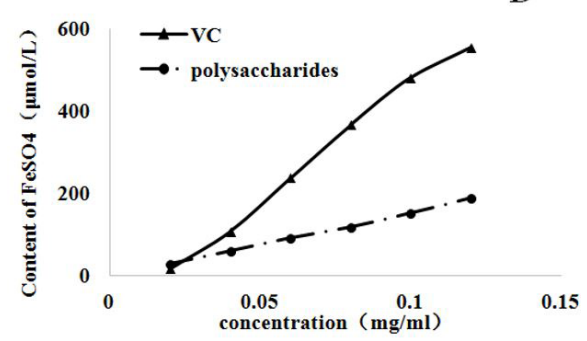

Figure 2. Antioxidant and free radical scavenging activities of Galla Chinensis polysaccharides. (A) DPPH assay; (B) ABTS assay; (C) Total antioxidant activity test; (D) Iron ion reduction assay (FRAP). VC: Vitamin C. 
A
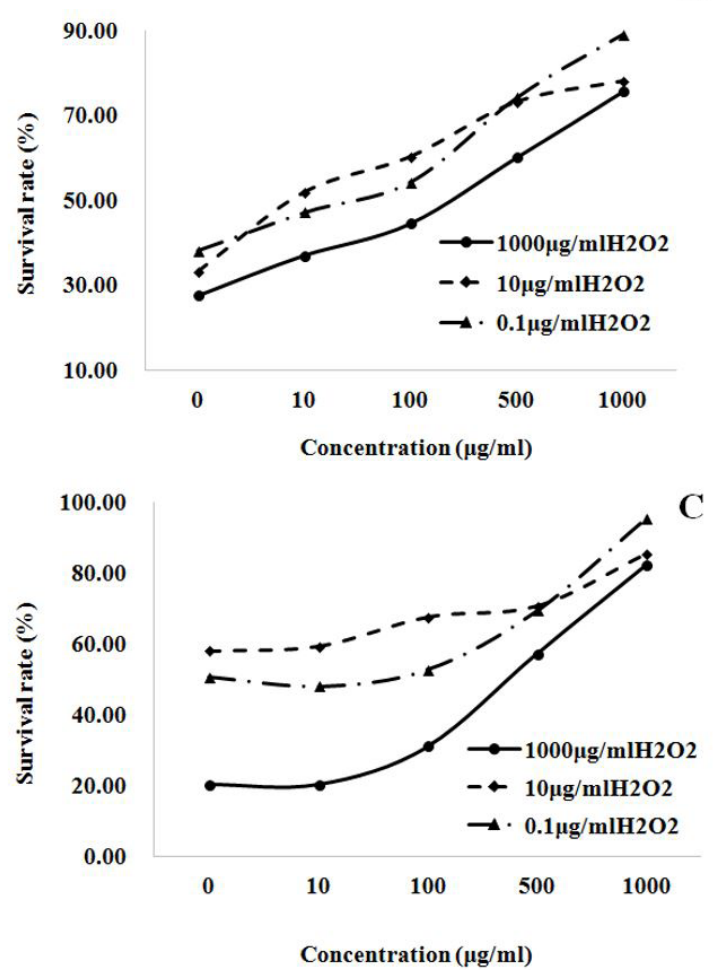

(1)
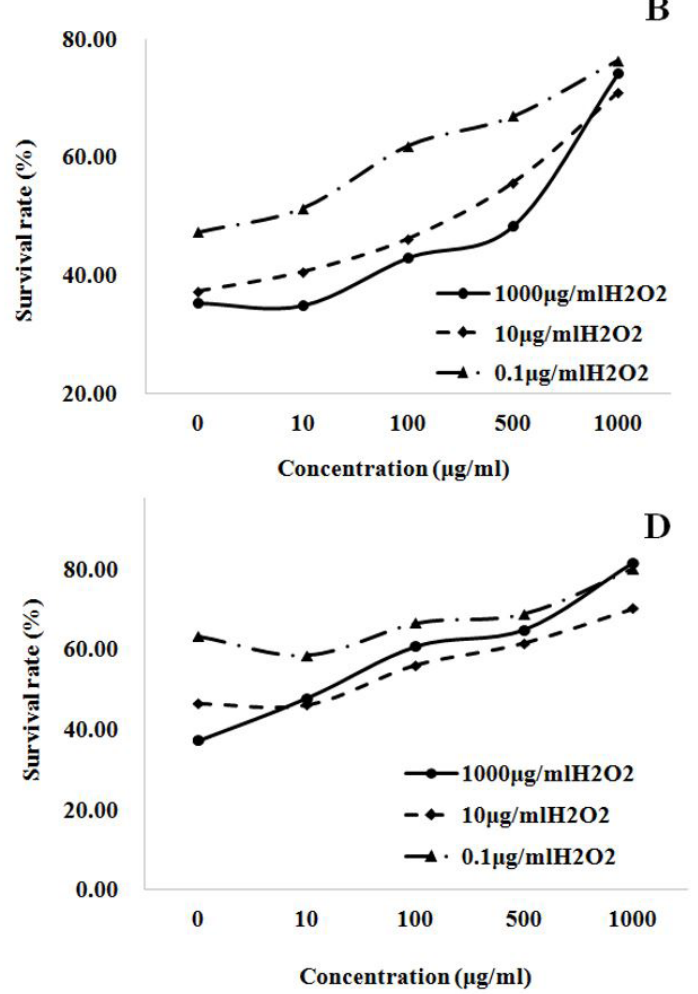

Figure 3. Cellular antioxidant activities of Galla Chinensis polysaccharides. (A) 293 cells, $6 \mathrm{~h}$ treatment; (B) 293 cells, $24 \mathrm{~h}$ treatment; (C) 7721 cells, $6 \mathrm{~h}$ treatment; (D) 7721 cells, $24 \mathrm{~h}$ treatment.

high as $83 \%$ when the concentration of polysaccharides reached $0.18 \mathrm{mg} / \mathrm{mL}$. Moreover, polysaccharides of Galla Chinensis demonstrated stronger free radical scavenging effects against ABTS in the test. It could clear almost $100 \%$ free radicals at concentration of $0.06 \mathrm{mg} / \mathrm{mL}$, while vitamin $\mathrm{C}$ achieved the similar effects at concentration of $0.02 \mathrm{mg} / \mathrm{mL}$ (Figure $2 \mathrm{~B}$ ). Compared to that of vitamin $\mathrm{C}$, the antioxidant activity of Galla Chinensis polysaccharides were relatively weak in the total antioxidant assay. At the dose of $0.36 \mathrm{mg} / \mathrm{mL}$ (maximum value tested), the antioxidant effects of polysaccharides were about $12.4 \%$ of those of vitamin $\mathrm{C}$ (Figure 2C). In the iron ion reduction assay, both of vitamin C and Galla Chinensis polysaccharides demonstrated effectively reductive ability of ferrous ions in the dose-dependent manner. At the concentration of $0.12 \mathrm{mg} / \mathrm{mL}$, the amount of ferrous ion reduced by vitamin $C$ solution could reach $553.99 \mu \mathrm{mol} / \mathrm{L}$, while that of polysaccharide solution reached $189.31 \mu \mathrm{mol} / \mathrm{L}$ (Figure 2D). Taken together, polysaccharides of Galla Chinensis presented nearly similar free radicals scavenging effects as vitamin C. It also behaved antioxidant and reductive ability which were not as stronger as those of vitamin C.

As shown in Figure 3, polysaccharides of Galla Chinensis presented effectively protection against $\mathrm{H}_{2} \mathrm{O}_{2}$-induced oxidative damage on both of tested cell lines, including the human embryonic kidneyfibroblast cells 293 and human hepatoma cells 7721, in a dose-dependent manner after 6 and 24 hour treatment.

In 293 cells, the higher concentration of the hydrogen peroxide could lead to the lower survival rate of the cells. After polysaccharides were added, the cell survival rate was significantly increased. At the maximum concentration of polysaccharides $(1000 \mu \mathrm{g} / \mathrm{mL})$, the cell survival rate reached $75 \%, 78 \%$ and $89 \%$ in $1000 \mu \mathrm{g} / \mathrm{mL}, 10 \mu \mathrm{g} / \mathrm{mL}$ and $0.1 \mu \mathrm{g} / \mathrm{mL}$ $\mathrm{H}_{2} \mathrm{O}_{2}$ treatment groups at 6 hours, respectively (Figure $3 \mathrm{~A}$ ). At 24 hour, these numbers were $74 \%, 71 \%$ and $76 \%$ in $1000 \mu \mathrm{g} / \mathrm{mL}$, $10 \mu \mathrm{g} / \mathrm{mL}$ and $0.1 \mu \mathrm{g} / \mathrm{mL} \mathrm{H}_{2} \mathrm{O}_{2}$ treatment groups, respectively (Figure 3B).

In 7721 cells, polysaccharides of Galla Chinensis showed great antioxidant activities as well. The higher concentrations could achieve higher survival rate of cells. At the concentration of $1000 \mu \mathrm{g} / \mathrm{mL}$, polysaccharides could protect $82 \%, 85 \%$ and $95 \%$ cells out of oxidative damage by $1000 \mu \mathrm{g} / \mathrm{mL}, 10 \mu \mathrm{g} / \mathrm{mL}$ and $0.1 \mu \mathrm{g} / \mathrm{mL} \mathrm{H}_{2} \mathrm{O}_{2} 6$ hour's treatment, respectively (Figure 3C). These protective effects could last at least 24 hours. The cell survival rate could be maintained at $81 \%, 70 \%$ and $80 \%$ in $1000 \mu \mathrm{g} / \mathrm{mL}$, $10 \mu \mathrm{g} / \mathrm{mL}$ and $0.1 \mu \mathrm{g} / \mathrm{mL} \mathrm{H}_{2} \mathrm{O}_{2}$ treatment groups at 24 hours, respectively (Figure $3 \mathrm{D}$ ).

Excessively high levels of free radicals could initiate lipid peroxidation, cause oxidative damage to cellular proteins, membrane lipids and nucleic acids, resulting in cells, tissues and organ injury (Maritim et al., 2003). The chronic oxidative damage currently has been exemplified to increase the risk of cancers, type 2 diabetes mellitus, coronary artery disease, atherosclerosis and neurodegenerative disease (Li et al., 2015; Lushchak, 2014). Meanwhile, natural polysaccharides isolated from traditional herbal medicines are a type of agents with promising therapeutic potentials to be developed as novel adjuvant or even clinical drugs for future use in the treatment of oxidative damage diseases (Shi, 2016). In this study, the antioxidant and free radical scavenging activities of polysaccharides from Galla Chinensis were determined 
for the first time. Especially, its free radical scavenging effects were as strong as those of Vitamin $\mathrm{C}$ and much stronger than those of many natural polysaccharides reported in literature. To achieve over $80 \%$ DPPH radical scavenging rates, the concentration of Galla Chinensis polysaccharides was $0.18 \mathrm{mg} / \mathrm{mL}$, which the concentration of Lilium davidii polysaccharides was $2 \mathrm{mg} / \mathrm{mL}$ (Hui et al., 2019). Moreover, the polysaccharides of Hovenia dulcis and Viscum coloratum should reach $4 \mathrm{mg} / \mathrm{mL}$ and $6 \mathrm{mg} / \mathrm{mL}$ to obtain the similar effect (Chai et al., 2019; Yang et al., 2019). To achieve $60 \%$ ABST radical scavenging rates, the concentration of polysaccharides was $0.03 \mathrm{mg} / \mathrm{mL}, 2 \mathrm{mg} / \mathrm{mL}$ and $4 \mathrm{mg} / \mathrm{mL}$ for Galla Chinensis, Hovenia dulcis and Lilium davidii, respectively (Hui et al., 2019; Yang et al., 2019). In addition, the protective effects of Galla Chinensis polysaccharides under oxidative damage were firstly determined on two types of human cell lines in vitro. Under strong oxidant agent $\mathrm{H}_{2} \mathrm{O}_{2}$ treatment, Galla Chinensis polysaccharides could effectively increase the cell survival compared to cells without protection. The survival rates of cells remained constant level from 6 hours to 24 hours, thus proving the persistence effect of this protection. Though the underlying mechanisms of this protection were unclear yet, the similar antioxidant pharmacological mechanisms of natural polysaccharides have been broadly investigated in both of in vitro and in vivo oxidative models. Those could be related to the regulation of various signaling pathways through a wide range of enzymic and non-enzymic antioxidants, such as superoxide dismutase (SOD), catalase (CAT), malondialdehyde (MDA), reduced glutathione $(\mathrm{GSH})$, glutathione peroxidase $(\mathrm{GPx})$ and glutathione reductase (GR) (Liu et al., 2019; Xu et al., 2019). Therefore, further investigation into the roles of polysaccharides of Galla Chinensis in those potential targets remains as an ongoing challenge. Taken together, the finding in this study firstly determined polysaccharides as an effective antioxidant ingredient from Galla Chinensis, thus providing a valuable natural antioxidant for further investigation and development.

\section{Conclusion}

In this study, an ultrasonic-assisted method has been developed to extract the polysaccharides from Galla Chinensis through response surface optimization. Its antioxidant activities were further evaluated and confirmed in chemical and cellular oxidative models in vitro. The results firstly determined that polysaccharides were a significant group of bioactive components constitute the antioxidant effects of Galla Chinensis. The further studies are strongly suggested to characterize the composition of Galla Chinensis polysaccharides and then explore its pharmacological mechanisms underlying antioxidant effects. Moreover, it strongly underpinned a fundamental understanding of antioxidant activities of herb Galla Chinensis and supports its ongoing clinical uses in China.

\section{References}

Bargougui, K., Athmouni, K., \& Chaieb, M. (2019). Optimization, characterization and hepatoprotective effect of polysaccharides isolated from Stipa parviflora Desf. against $\mathrm{CCl}_{4}$ induced liver injury in rats using surface response methodology (RSM). International Journal of Biological Macromolecules, 132, 524-533. http://dx.doi. org/10.1016/j.ijbiomac.2019.03.216. PMid:30936007.
Chai, Y., Kan, L., \& Zhao, M. (2019). Enzymatic extraction optimization, anti-HBV and antioxidant activities of polysaccharides from Viscum coloratum (Kom.) Nakai. International Journal of Biological Macromolecules, 134, 588-594. http://dx.doi.org/10.1016/j. ijbiomac.2019.04.173. PMid:31029628.

Chen, C., Li, B., Cheng, G. Q., Yang, X. N., Zhao, N. N., \& Shi, R. (2018). Amentoflavone ameliorates A $\beta 1$-42-induced memory deficits and oxidative stress in cellular and rat model. Neurochemical Research, 43(4), 857-868. http://dx.doi.org/10.1007/s11064-018-2489-8. PMid:29411261.

Chen, F., \& Huang, G. L. (2019). Antioxidant activity of polysaccharides from different sources of ginseng. International Journal of Biological Macromolecules, 125, 906-908. http://dx.doi.org/10.1016/j. ijbiomac.2018.12.134. PMid:30572039.

Farbood, Y., Rashno, M., Ghaderi, S., Khoshnam, S. E., Sarkaki, A., Rashidi, K., Rashno, M., \& Badavi, M. (2019). Ellagic acid protects against diabetes-associated behavioral deficits in rats: possible involved mechanisms. Life Sciences, 225, 8-19. http://dx.doi.org/10.1016/j. lfs.2019.03.078. PMid:30943382.

Gao, J. Y., Yang, X., Hu, J. X., \& Yang, X. (2019). Polysaccharides of Spina Gleditsiae: a potential treasure in anticancer and antioxidant drug discovery. International Journal of Pharmacology, 15(1), 144-150. http://dx.doi.org/10.3923/ijp.2019.144.150.

Gao, J. Y., Yang, X., Liu, P., \& Yin, W. P. (2016). Optimization of ultrasonic-assisted extraction of polysaccharides from Scutellaria barbata and determination of their anticancer and antioxidant activities. International Journal of Pharmacology, 12(7), 754-759. http://dx.doi.org/10.3923/ijp.2016.754.759.

Gao, J. Y., Yang, X., Yin, W. P., \& Li, M. (2018). Gallnuts: a potential treasure in anticancer drug discovery. Evidence-Based Complementary and Alternative Medicine, 2018, 4930371. http:// dx.doi.org/10.1155/2018/4930371. PMid:29785193.

Hui, H. P., Jin, H., Li, X. Z., Yang, X. Y., Cui, H. Y., Xin, A. Y., Zhao, R. M., \& Qin, B. (2019). Purification, characterization and antioxidant activities of a polysaccharide from the roots of Lilium davidii var. unicolor Cotton. International Journal of Biological Macromolecules, 135, 1208-1216. http://dx.doi.org/10.1016/j.ijbiomac.2019.06.030. PMid:31176857.

Kahkeshani, N., Farzaei, F., Fotouhi, M., Alavi, S. S., Bahramsoltani, R., Naseri, R., Momtaz, S., Abbasabadi, Z., Rahimi, R., Farzaei, M. H., \& Bishayee, A. (2019). Pharmacological effects of gallic acid in health and diseases: a mechanistic review. Iranian Journal of Basic Medical Sciences., 22(3), 225-237. PMid:31156781.

Li, S., Tan, H. Y., Wang, N., Zhang, Z. J., Lao, L. X., Wong, C. W., \& Feng, Y. B. (2015). The role of oxidative stress and antioxidants in liver diseases. International Journal of Molecular Sciences, 16(11), 2608726124. http://dx.doi.org/10.3390/ijms161125942. PMid:26540040.

Liu, X. C., Pang, H., Gao, Z., Zhao, H. J., Zhang, J. J., \& Jia, L. (2019). Antioxidant and hepatoprotective activities of residue polysaccharides by check for Pleurotus citrinipileatus. International Journal of Biological Macromolecules, 131, 315-322. http://dx.doi.org/10.1016/j. ijbiomac.2019.03.074. PMid:30872051.

Liu, Y., Sun, Y. Y., \& Huang, G. L. (2018). Preparation and antioxidant activities of important traditional plant polysaccharides. International Journal of Biological Macromolecules, 111, 780-786. http://dx.doi. org/10.1016/j.ijbiomac.2018.01.086. PMid:29355627.

Lushchak, V. I. (2014). Free radicals, reactive oxygen species, oxidative stress and its classification. Chemico-Biological Interactions, 224, 164175. http://dx.doi.org/10.1016/j.cbi.2014.10.016. PMid:25452175.

Maritim, A. C., Sanders, R. A., \& Watkins, J. B. 3rd. (2003). Diabetes, oxidative stress, and antioxidants: a review. Journal of Biochemical 
and Molecular Toxicology, 17(1), 24-38. http://dx.doi.org/10.1002/ jbt.10058. PMid:12616644.

Ponnulakshmi, R., Shyamaladevi, B., Vijayalakshmi, P., \& Selvaraj, J. (2019). In silico and in vivo analysis to identify the antidiabetic activity of beta sitosterol in adipose tissue of high fat diet and sucrose induced type-2 diabetic experimental rats. Toxicology Mechanisms and Methods, 29(4), 276-290. http://dx.doi.org/10.1080/15376516. 2018.1545815. PMid:30461321.

Sariozlu, N. Y., \& Livanc, M. (2011). Gallnuts (Quercus infectoria Oliv. and Rhus chinensis Mill.) and their usage in health. nuts and seeds in health and disease prevention (Chapt. 60). London: Academic Press.

Shang, H. M., Li, R., Wu, H. X., \& Sun, Z. W. (2019). Polysaccharides from Trifolium repens $\mathrm{L}$. extracted by different methods and extraction condition optimization. Scientific Reports, 9(1), 6353. http://dx.doi. org/10.1038/s41598-019-42877-5. PMid:31015549.

Shi, L. (2016). Bioactivities, isolation and purification methods of polysaccharides from natural products: a review. International Journal of Biological Macromolecules, 92, 37-48. http://dx.doi.org/10.1016/j. ijbiomac.2016.06.100. PMid:27377457.

State Pharmacopoeia Committee of the People's Republic of China. (2015). Pharmacopoeia of the People's Republic of China. Beijing: Chemical Industry Press.

Wang, G., Wang, Y. Z., Yu, Y., \& Wang, J. J. (2019). Inhibitory ASIC2mediated calcineurin/NFAT against colorectal cancer by triterpenoids extracted from Rhus chinensis Mill. Journal of Ethnopharmacology, 235, 255-267. http://dx.doi.org/10.1016/j.jep.2019.02.029. PMid:30772482.
Xie, X. M., Zu, X. Y., Liu, F. F., Wang, T., Wang, X. Y., Chen, H. Y., Liu, K. D., Wang, P. L., Liu, F. F., Zheng, Y., Bode, A. M., Dong, Z. G., \& Kim, D. J. (2019). Purpurogallin is a novel mitogen-activated protein kinase kinase $1 / 2$ inhibitor that suppresses esophageal squamous cell carcinoma growth in vitro and in vivo. Molecular Carcinogenesis, 58(7), 1248-1259. http://dx.doi.org/10.1002/mc.23007. PMid:31100197.

Xu, Y., Zhang, X., Yan, X. H., Zhang, J. L., Wang, L. Y., Xue, H., Jiang, G. C., Ma, X. T., \& Liu, X. J. (2019). Characterization, hypolipidemic and antioxidant activities of degraded polysaccharides from Ganoderma lucidum. International Journal of Biological Macromolecules, 135, 706716. http://dx.doi.org/10.1016/j.ijbiomac.2019.05.166. PMid:31129213.

Xue, H. Y., Li, J. R., Liu, Y. G., Gao, Q., Wang, X. W., Zhang, J. W. Tanokura, M., \& Xue, Y. L. (2019). Optimization of the ultrafiltrationassisted extraction of Chinese yam polysaccharide using response surface methodology and its biological activity. International Journal of Biological Macromolecules, 121, 1186-1193. http://dx.doi. org/10.1016/j.ijbiomac.2018.10.126. PMid:30342144.

Yang, B., Wu, Q., Luo, Y., Yang, Q., Wei, X., \& Kan, J. (2019). High-pressure ultrasonic-assisted extraction of polysaccharides from Hovenia dulcis: extraction, structure, antioxidant activity and hypoglycemic. International Journal of Biological Macromolecules, 137, 676-687. http://dx.doi.org/10.1016/j.ijbiomac.2019.07.034. PMid:31284006.

Zhao, B., Lv, C. N., \& Lu, J. C. (2019). Natural occurring polysaccharides from Panax ginseng C. A. Meyer: a review of isolation, structures, and bioactivities. International Journal of Biological Macromolecules, 133, 324-336. http://dx.doi.org/10.1016/j.ijbiomac.2019.03.229. PMid:30943421. 